Original Research Paper

\title{
The Development of Nanotechnology Bentonite as Adsorbent of Copper Metal (Cu)
}

\author{
${ }^{1}$ Susila Arita, ${ }^{2}$ Muhammad Naswir, ${ }^{2}$ Irma Astriana and ${ }^{2}$ Nelson \\ ${ }^{I}$ Department of Chemistry, Faculty of Engineering, University of Sriwijaya, Indonesia \\ ${ }^{2}$ Department of Chemistry, Faculty of Science and Technology of the University of Jambi, \\ Street Jambi-Ma. Bulian KM 15. Post code. 36361 Mendalo Darat, Jambi, Indonesia
}

Article history

Received: 23-03-2018

Revised: 02-04-2018

Accepted: 14-04-2018

Corresponding Author:

Muhammad Naswir

Department of Chemistry,

Faculty of Science and

Technology of the University of Jambi, Street Jambi-Ma. Bulian

KM 15. Post code. 36361

Mendalo Darat, Jambi,

Indonesia

Email: m.naswir@yahoo.com

\begin{abstract}
The aims of the research to develop nanotechnology with the use of bentonite as adsorbent cooper metal $(\mathrm{Cu})$. Bentonite activation treatment performed. The parameters studied in this research is a variation of the mass of bentonite, contact time and adsorption capacity. Measurements were made using AAS. Activation of bentonite using a solution of $\mathrm{HCl} 1.6 \mathrm{M}$. In experiments conducted bentonite weight variation of $0.1 ; 0.3$; and $0.5 \mathrm{gr}$ with a contact time of $30,60,90$ and $120 \mathrm{~s}$. The results showed that the decreased absorption of active bentonite is 96.8 and $99,7 \%$ bentonit not activated Thus discovered a new phenomenon which is not activated bentonite is have a better ability to absorb copper compared to the activated bentonite.
\end{abstract}

Keywords: Bentonite, Nanotechnology, Metal $\mathrm{Cu}$, Adsorption, AAS

\section{Introduction}

Disposal of industrial waste is continuously not only pollute the environment but lead to the accumulation ofheavy metals in sediments and biota (Hutagalung, 1991). Heavy metal is a metal element with a relative molecular mass larger than with other metal elements such as alkali and alkaline earth metals (Notohadiprawiro, 1993). Even low levels of heavy metals are generally toxic to plants and animals, including humans. Efforts to tackle high levels of metals can be done with the adsorption process (Sembiring et al., 2009). One of the heavy metals that are harmful to the environment and the human body when the concentration exceeds a threshold that is metallic copper $(\mathrm{Cu})$, because these metals are toxic and are not needed by the human body, when mankind is contaminated by heavy metals can cause high blood pressure, kidney tissue damage testibuler, lung cancer and damage to the red blood cells of kidney and liver damage and cardiovascular disorders. $\mathrm{Cu}$ hazardous if the concentration exceeds that of the corresponding recommended. Terms of the water quality standards that is a threshold level of $\mathrm{Cu}$ (II) to water class $\mathrm{A}$ (for drinking water) of $1.0 \mathrm{mg} \mathrm{L}^{-1}$ of class $\mathrm{B}$ (for drinking water) $1.0 \mathrm{mg} \mathrm{L}^{-1}$, class $\mathrm{C}$ (for fishing) $0,02 \mathrm{mg} \mathrm{L}^{-1}$ and class D (for agriculture, industry, hydropower) $0.2 \mathrm{mg}$ $\mathrm{L}^{-1}$ (Government regulation No. 20 of 1990).
To reduce the levels of $\mathrm{Cu}$ in the wastewater, the adsorption of $\mathrm{Cu}$ can be done by using the adsorbent is bentonite. Bentonite has two layers of different interlayer so that the bentonite has a high cation exchange capability, because the bentonite is a good adsorbent for absorbing organic compound or pesticide, dye and heavy metal ions (Faizal, 2014). Deposits of bentonite in Jambi province are known in three areas, namely the Bangko district with an area of 4400 hectares, Bungo Tebo $=520$ hectares and Batang Hari hectare $=1350$. Bentonite has been used for processing some parameters on peat water into clean water. and most likely bentonite can also be used for absorption of copper metals in the environment (Naswir et al., 2015).

The method is commonly used for the management of heavy metals in the environment is a method presiptation, electrogravimetr, separation, membrane and adsorption. In a research method developed is the adsorption method, because this method has the advantage of a cheaper, simpler, easier critical operations and have a great capacity (Christidis et al., 1997). The adsorbent used is bentonite. Bentonite has a good adsorption capacity, power exchange cations and anions are good. Bentonite as an adsorbent needs to be activated in advance and determined the optimum conditions before being used for the absorption process in order to work more absorbency maximal. So in this research will be to learn how efficient absorption of bentonite to 
metallic copper $(\mathrm{Cu})$, optimal conditions and how capacity adsorption.

\section{Research Methodology}

\section{Materials and Equipment}

Materials used in this research is the region's natural bentonite precisely Jambi Regency Tanjung area Biku Merangin, $\mathrm{HCl}$, distilled, crystal $\mathrm{CuSO}_{4} .5 \mathrm{H}_{2} \mathrm{O}$ and filter paper. The equipment used consisted of a set of glassware such as beakers, erlenmeyer, long neck flask, 200 mesh strainer, shaker, oven, grinder and measurement instruments for Copper $(\mathrm{Cu})$ using Atomic Absorption Spectrophotometry (AAS).

\section{Preparation and Activation of Bentonite}

Bentonite samples taken in the area Biku Tanjung packed in sacks, then performed the sample preparation by softening and drying with hot sun,then followed by drying in an oven at $105^{\circ} \mathrm{C}$ for $24 \mathrm{~h}$ which aims to eliminate moisture (heat activation). Bentonite which has been dried crushed and pulverized to 200 mesh size nanometer. Once that is done the activation of bentonite with $500 \mathrm{~g}$ of bentonite with a size of 100 mesh immersed in $1000 \mathrm{~mL}$ of $1.6 \mathrm{M} \mathrm{HCl}$ while stirring for one hour at $100 \mathrm{rpm}$ and then filtered and washed with distilled water. The resulting residue is heated to a temperature of $200^{\circ} \mathrm{C}$ for one hour Once dried, crushed to powder measuring nanogram to 200 mesh sieve. Activated bentonite obtained is used for the absorption of copper metal.

\section{Preparation of Standard Copper (Cu)}

In making the reagents used are crystal $\mathrm{CuSO}_{4} .5 \mathrm{H}_{2} \mathrm{O}$, then diluted with distilled water in a measuring cup and matched volume of $1000 \mathrm{~mL}$ with distilled water, then the resulting stock solution $\mathrm{Cu} 1000$ ppm. Copper 1000 ppm standard solution of $2.5 \mathrm{~mL}$ were taken and then put in a $250 \mathrm{ml}$ volumetric flask and diluted with distilled water to mark boundaries to obtain a standard solution of $10 \mathrm{ppm}$. Standard solution of $10 \mathrm{ppm}$ were taken $10 \mathrm{~mL}, 20 \mathrm{~mL}, 30 \mathrm{~mL}, 40 \mathrm{~mL}, 50 \mathrm{~mL}$ and diluted in $100 \mathrm{ml}$ volumetric flask to obtain standard solution 1, 2, 3, 4 and 5 ppm

Copper (Cu) Concentration Measurements with Mass Variation and Contact Time

Each bentonite $0.1 ; 0.3$ and $0.5 \mathrm{~g}$ which has not been activated incorporated into the beaker and then added 50 $\mathrm{mL}$ solution of $1 \mathrm{ppm} \mathrm{CuSO}_{4} \cdot 5 \mathrm{H}_{2} \mathrm{O}$ into each glass. The solution will be stirred using a shaker speed of $200 \mathrm{rpm}$ for $1 \mathrm{~h}$. Variation 30, 60, 90 and $120 \mathrm{~min}$. The solution is filtered to separate the filtrate and the residue. The filtrate obtained was analyzed by AAS.

\section{Analysis Data}

The concentration of the sample solution is determined by substituting the price sample absorbance (y) obtained from the data AAS through linear regression line equation $Y=a x+b$ (Miller and Miller, 1991). Copper calibration curve obtained by plotting the concentration of the copper standard solution to the absorbance. To determine the absorption efficiency of metal cadmium used the formula:

$\%$ Efisiensi Absorption $=\frac{C o-C a}{C a} \times 100 \%$

note: $C o=$ initial concentration, $C a=$ Concentration end.

Calculation of adsorption capacity (Qe) Cd metal with the formula:

$Q e=\frac{(\text { Iinitial concentration }- \text { concentration and })}{\text { adsorbent } \text { mass }}$

\section{Results and Discussion}

\section{Characterization of Bentonite}

Bentonite can be applied as an adsorbent for memeiliki extensive surface, porous and have active sites. Bentonite is a mineral alumina silicate hydrate included in pilosilikat, or layered silicates. General chemical formula bentonite is $\mathrm{Al}_{2} \mathrm{O}_{3} \cdot 4 \mathrm{SiO}_{2} \cdot \mathrm{H}_{2} \mathrm{O}$. The content consists of monmorilonite bentonite, illite and quartz which $85 \%$ of its content in the form of montmorillonite (Apriliana and Dewi, 2015). Bentonite Biku Tanjung Province of Jambi contains minerals monmorrilonit, quarsa, cristobalite and kaolinite as in Fig. 1 (Naswir et al., 20013).

The bentonite composition of the Tanjung Biku area is determined using the SEM-EDS instrument, as listed in Table 1 (Naswir et al., 2013).

Table 1: Composition of bentonite Biku Tanjung Jambi Province

\begin{tabular}{lc}
\hline Komponen & \% berat \\
\hline $\mathrm{SiO}_{2}$ & 44.11 \\
$\mathrm{Al}_{2} \mathrm{O}_{3}$ & 33.61 \\
$\mathrm{TiO}_{2}$ & 0.66 \\
$\mathrm{CaO}$ & 0.01 \\
$\mathrm{MgO}$ & 0.19 \\
$\mathrm{~K}_{2} \mathrm{O}$ & 0.04 \\
$\mathrm{Na} \mathrm{O}_{2} \mathrm{O}$ & - \\
$\mathrm{FeO}$ & 2.22 \\
$\mathrm{CuO}$ & 3.85 \\
$\mathrm{C}$ & 14.24 \\
\hline
\end{tabular}




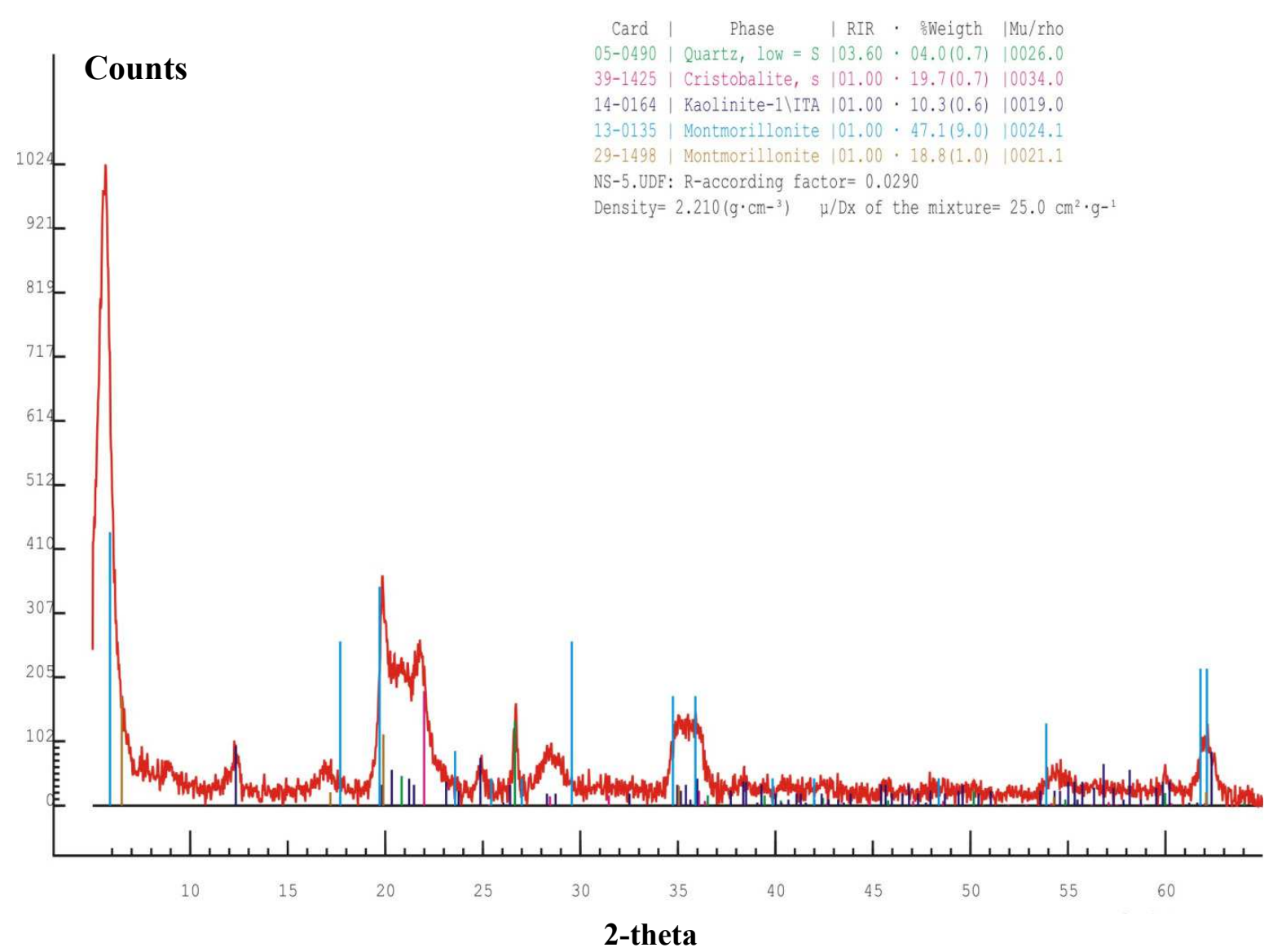

Fig. 1: Spectrum XRD Bentonit of The Biku Tanjung (Naswir et al., 2013)

From Table 1 it is known that bentonite has some chemical components that cause the bentonite can adsorb, in addition to the adsorption properties of bentonite is because the particle size is very small and has a high capacity ion surface (Naswir et al., 2013). Absorptive capacity will be increased if activated bentonite both physics and chemistry. Activation aims to eliminate impurity/impurities that accompany the natural clay (Prasetyowati et al., 2014).

\section{Measurement of Copper (Cu)}

The resulting absorbance is directly proportional to the concentration of the standard solution ie the greater the concentration used, the absorbency also getting bigger. Having obtained the absorbent of the standard solution, then graphed the relationship between the concentration by absorbent then be producedlinear regression calibration curve in getting to channel the concentration of standard solution as $\mathrm{X}$-axis is plotted against the $\mathrm{Y}$ axis absorbency as obtained from measurement data at AAS. Standard calibration curve obtained produce regression equation $\mathrm{y}=0,127 \mathrm{x}$.

\section{Measurement of Mass Variation and Contact Time}

Bentonite used mass variation affects the absorption occurs, this can be illustrated in Fig. 2

From Fig. 2. The above can be seen in the treatment of active bentonite weighing 0.1 grams of $\mathrm{Cu}$ uptake by $96.8 \%$, with a weight of 0.3 grams of $\mathrm{Cu}$ absorption amounted to $90.7 \%$, but with bentonite which is inactive with a weight of 0.1 grams of $\mathrm{Cu}$ absorption of $99.7 \%$, with a weight 0.3 grams of $\mathrm{Cu}$ absorption of $100 \%$. In active bentonite is shown in the graph shows that the increased weight of bentonite absorption of $\mathrm{Cu}$ decreased, this is due to overly saturated $\mathrm{HCl}$ used in the activation (Apriliana and Dewi, 2015). According to (Ramadani and Eko, 2011), the increasing concentration of the acid will produce larger active site so that it will produce an active site that has a better adsorption capacity.

Research conducted by Bath (2012) showed that bentonite (West Java) activated by using $\mathrm{HCl}$ has absorption to $\mathrm{Cu}$ of $99.16 \%$, while research by Ramdani by using $\mathrm{H}_{2} \mathrm{SO}_{4}$ activator showed absorption to $\mathrm{Cu}$ is equal to 84,11 and $90,32 \%$ (Ramadani and Eko, 2011) beside that other experts who do research on the absorption of natural bentonite to metal $\mathrm{Cu}$, with good 
result (Yusnimar and Drastiwati, 2005). Ion exchange reaction is a special form of chemical adsorption. Ion exchange can take place if the majority $\mathrm{Cu}$ adsorbent replace the existing position of positive ions in the bentonite adsobent, so that the positive ions migrate into the liquid (Al-Jlil, 2010). This is because there is the Coulomb force between negatively charged ions contained no adsorbent with positive ions such as $\mathrm{Cu}$ as adsorbate, bonding can occur electrostatic bond (Apriliana and Dewi, 2015; Komadel, 2003).

On absorption of $\mathrm{Cu}$ using bentonite is not yet active percent absorption efficiency of $100 \%$ with a contact time of $30 \mathrm{~min}$. This contact time is the time used by the adsorbent and adsorbate to interact directly. If the liquid phase containing the adsorbent silent, then the adsorbate diffusion through the surface of the adsorbent will be slow. It is therefore necessary agitation to accelerate the process of adsorption (Weber, 1972). According to Suarya the increased absorption of adsorbate by the adsorbent shows yet saturated adsorbent active sites by adsorbed molecules, but the weight of the adsorbate adsorbed conditionhave been caused by the constant saturation of active sites of the adsorbent by adsorbate molecules (Suarya, 2008).

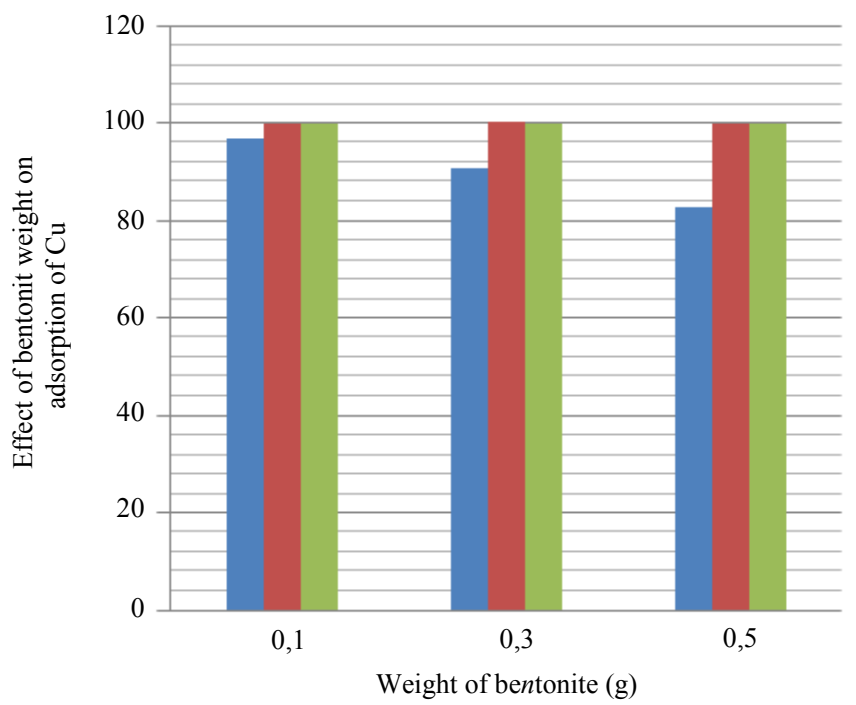

Bentonite aktive

Bentonite non aktivated

Commercial bentonite

(a)

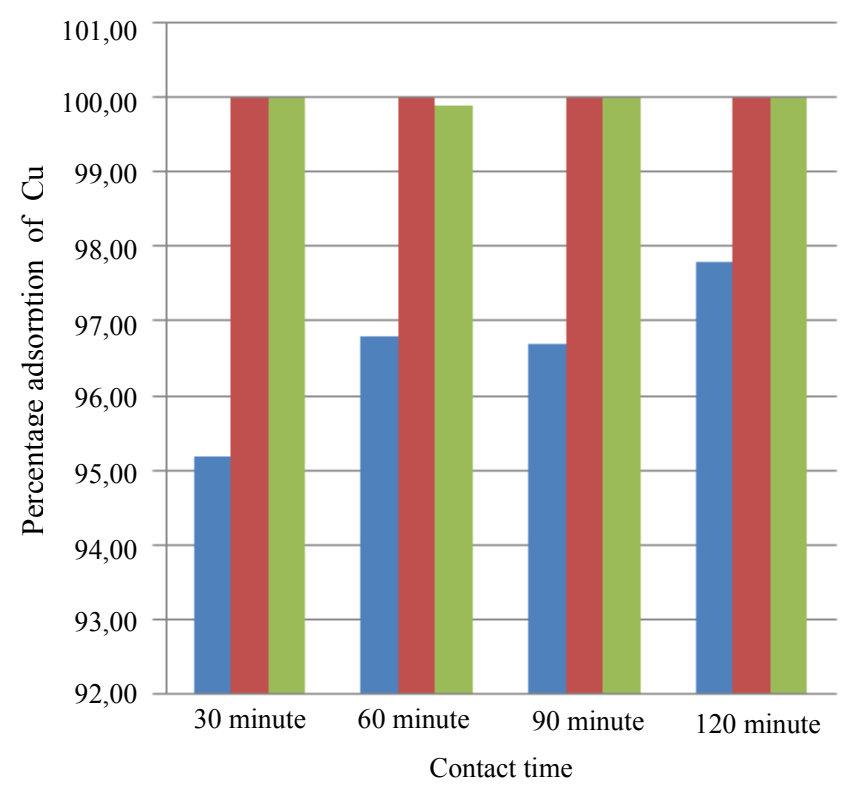

Bentonite aktive

Bentonite not activated

Commercial bentonite

(b)

Fig. 2: Graph of weight variation (a) and contact time (b) of bentonite to the adsorption of $\mathrm{Cu}$ 
With activation can enlarge the pores do that is by oxidize molecules adsorbent surface so that the physical and chemical changes, namely the surface area increase in size and influence on the adsorption capacity (Salamah, 2008). Activation of bentonite can be done in two ways, namely by physics and chemistry. Chemical activation is done by acid or base. The chemicals that are often used as an activator is $\mathrm{H}_{3} \mathrm{PO}_{4}$.

$\mathrm{ZnCl}_{2}, \mathrm{CaCl}_{2}, \mathrm{~K}_{2} \mathrm{~S}, \mathrm{HCl}, \mathrm{H}_{2} \mathrm{SO}_{4}, \mathrm{NaCl}, \mathrm{Na}_{2} \mathrm{CO}_{3}$ (Istighfaro, 2010). Bentonite can be used as an adsorbent for most of its crystal structure consisting of montmorillonite (smectite) with type 2: 1 i.e., $2 \mathrm{SiO}_{2}: \mathrm{AlO}_{3}$ (Fatimah, 2014) as adsorbent and widely applied in the adsorption process. Bentonite is a mineral alumina silicate hydrate included in pilosilikat, or layered silicates. General chemical formula bentonite is $\mathrm{Al}_{2} \mathrm{O}_{3} \cdot 4 \mathrm{SiO}_{2} \cdot \mathrm{H}_{2} \mathrm{O}$. The content consists of monmorilonite bentonite, illite and quartz which $85 \%$ of its content in the form of montmorillonite. The plated 2: 1 layer structure between the basic structural units results in the proximity of two oxygen atoms from the tangent tetrahedral layers, so that the basic structural units repel each other and result in the expansion of clay minerals which form the active site of an addition so that the active site is more than one layer.

For a 2: 1 layered structure the embankment between the basic structural units results in the proximity of two oxygen atoms of the tangent tetrahedral layers, so that the basic structural units repel each other and result in the expansion of clay minerals which form the active site of an additional so-called intermediate site layer internal), The existence of sites between these layers is a special feature of the clay-coated mineral structure with 2: 1 (Sainz-Diaz et al., 2001). Bentonite is masked with a large surface including nanotechnologies, a large surface formed by many fine pores in bonding. Usually the extent is about $200-1000 \mathrm{~m}^{2} / \mathrm{g}$ of adsorbent, with a pore diameter of 0.0003 to $0.02 \mu$.

\section{Adsorption Capacity}

Adsorption capacity is used to describe the relationship between the adsorbent and the adsorbed substance in an equilibrium. There are two models used to determine the adsorption isotherm is Langmuir and Freundlich isotherm models. The process of absorption or adsorption by an adsorbent is influenced by many factors and also has a pattern within specific adsorption isotherms so adsorbent which absorbs a substance one with another substance would not have the same pattern of the adsorption isotherm. $\mathrm{Cu}$ absorption measurement results after the addition of bentonite can be summarized in Table 2 .

Langmuir isotherm is based on the assumption that the adsorbent has a homogeneous surface, adsorption energy is constant in all sides, all equally adsorption process each adsorbent surface and each side of the adsorbent can only absorb one adsorbate molecule. The following chart Langmuir isotherm calculation result of bentonite active in absorbing $\mathrm{Cu}$.

Table 2: Results of measurement of the concentration of $\mathrm{Cu}$ after treatment

\begin{tabular}{|c|c|c|c|c|c|c|c|}
\hline $\begin{array}{l}\mathrm{C} \text { initial } \\
\mathrm{Cu}(\mathrm{ppm}) \\
\mathrm{Co}\end{array}$ & $\begin{array}{l}\mathrm{C} \text { endr } \\
\mathrm{Cu}(\mathrm{ppm}) \\
\mathrm{Ce}\end{array}$ & $\begin{array}{l}\text { Volume } \\
\text { (L) }\end{array}$ & $\begin{array}{l}\text { Wight } \\
\text { bentonite (gr) } \\
\text { M }\end{array}$ & $\begin{array}{l}\text { Amount } \\
(\mathrm{mg} / \mathrm{g}) \\
\mathrm{Qe}\end{array}$ & $\mathrm{Ce} / \mathrm{Qe}(\mathrm{g} / \mathrm{L})$ & $\log \mathrm{Ca}$ & Log Qe \\
\hline 1 & 0.032 & 0.5 & 0.1 & 0.48400 & 0.06610 & -1.494 & -0.3150 \\
\hline 1 & 0.093 & 0.5 & 0.3 & 0.15116 & 0.61524 & -1.032 & -0.8200 \\
\hline 1 & 0.175 & 0.5 & 0.5 & 0.0825 & 2.12120 & -0.757 & -1.0830 \\
\hline \multicolumn{8}{|c|}{ Variation of weight bentonite acktive } \\
\hline Co & $\mathrm{Ce}$ & & M & Qe & & & \\
\hline 1 & 0.003 & 0.5 & 0.1 & 0.4985 & 0.00602 & -2.5228 & -0.3020 \\
\hline 1 & 0.000 & 0.5 & 0.3 & 0.1667 & 0.00000 & $-\infty$ & -0.7780 \\
\hline 1 & 0.001 & 0.5 & 0.5 & 0.0999 & 0.01001 & -3.0000 & -1.0004 \\
\hline \multicolumn{8}{|c|}{ Variation of wieght bentonite inactive } \\
\hline Co & $\mathrm{Ce}$ & & M & Qe & & & \\
\hline 1 & 0.002 & 0.5 & 0.1 & 0.4990 & 0.004008 & -2.698 & -0.3020 \\
\hline 1 & 0.002 & 0.5 & 0.3 & 0.1663 & 0.012020 & -2.698 & -0.7790 \\
\hline 1 & 0.001 & 0.5 & 0.5 & 0.0999 & 0.010010 & -3.000 & -1.0004 \\
\hline \multicolumn{8}{|c|}{ Variation of contact time bentonite active } \\
\hline Co & $\mathrm{Ce}$ & & M & Qe & & & \\
\hline 1 & $\operatorname{Ttd}$ & 0.05 & 0.3 & 0.1667 & 0.000000 & $-\infty$ & -0.7780 \\
\hline 1 & Ttd & 0.05 & 0.3 & 0.1667 & 0.000000 & $-\infty$ & -0.7780 \\
\hline 1 & $\operatorname{Ttd}$ & 0.05 & 0.3 & 0.1667 & 0.000000 & $-\infty$ & -0.7780 \\
\hline 1 & $\operatorname{Ttd}$ & 0.05 & 0.3 & 0.1667 & 0.000000 & $-\infty$ & -0.7780 \\
\hline \multicolumn{8}{|c|}{ Variation of contact time bentonite inactive } \\
\hline Co & $\mathrm{Ce}$ & & M & Qe & & & \\
\hline 1 & Ttd & 0.05 & 0.5 & 0.1000 & 0.000000 & $-\infty$ & -1.0000 \\
\hline 1 & 0.001 & 0.05 & 0.5 & 0.0999 & 0.010010 & $-\infty$ & -1.0004 \\
\hline 1 & $\operatorname{Ttd}$ & 0.05 & 0.5 & 0.1000 & 0.000000 & $-\infty$ & -1.0000 \\
\hline 1 & $\operatorname{Ttd}$ & 0.05 & 0.5 & 0.1000 & 0.000000 & $-\infty$ & -1.0000 \\
\hline
\end{tabular}


Table 3: Results of the Langmuir isotherm of some types of bentonite and variations in time and contact time

\begin{tabular}{llll}
\hline & & Result & \\
Variation & Type Bentonite & $\mathrm{y}$ & $\mathrm{R}^{2}$ \\
\hline Massa bentonite & Aktive & $\mathrm{y}=14.59 \mathrm{x}-0.525$ & $\mathrm{R}^{2}=0.968$ \\
& In active & $\mathrm{y}=1.435 \mathrm{x}+0.003$ & $\mathrm{R}^{2}=0.189$ \\
& Commercials & $\mathrm{y}=1.996 \mathrm{x}+0.012$ & $\mathrm{R}^{2}=0.076$ \\
Contact time & Aktive & $\mathrm{y}=1.815 \mathrm{x}+0.025$ & $\mathrm{R}^{2}=0.261$ \\
& In active & 0 & 0 \\
& Commercials & $\mathrm{y}=10.01 \mathrm{x}$ & $\mathrm{R}^{2}=1$ \\
\hline
\end{tabular}

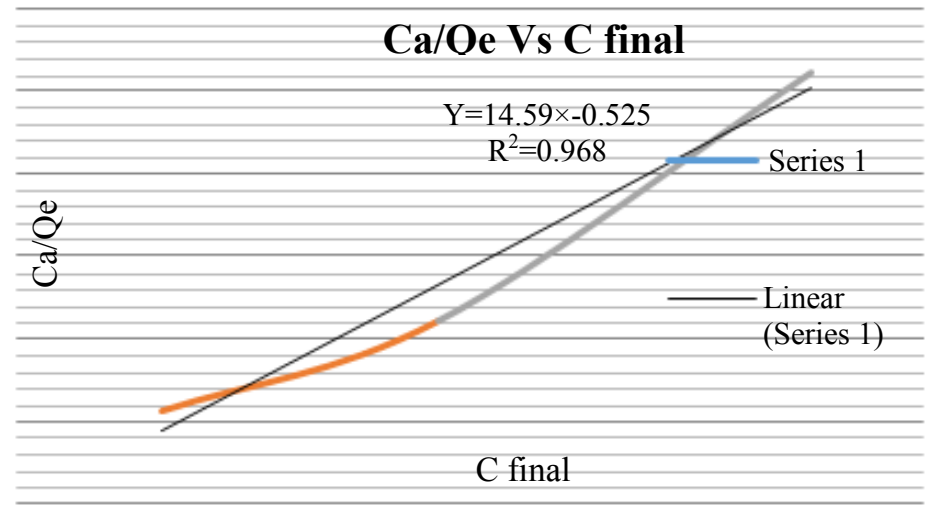

(a)

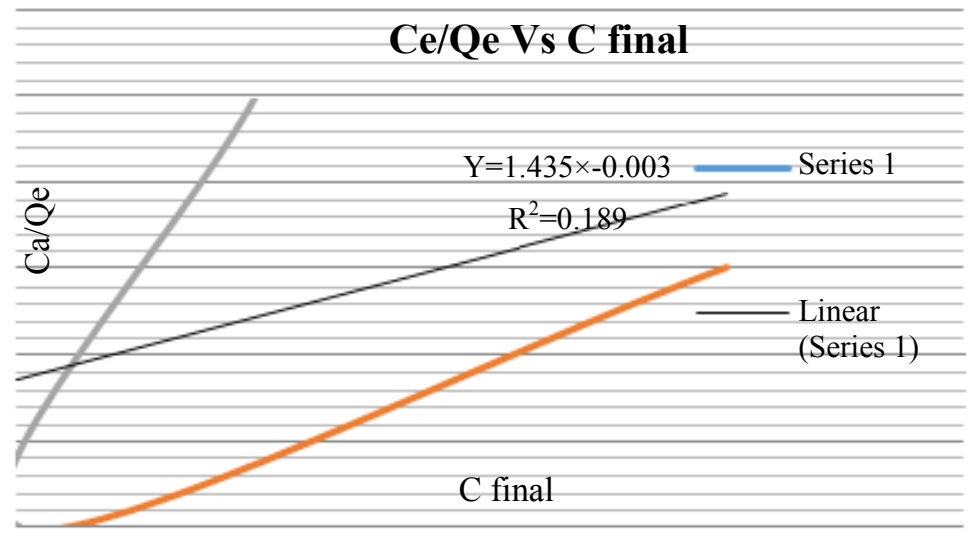

(b)

Fig. 3: (a) Langmuir isotherm bentonit active (b) Freudlick isotherm of inactive bentonite

Figure 3 shows a graph with the Langmuir isotherm active bentonite to produce a regression equation $\mathrm{y}=$ $14.59 x-0525$ and the value of $R^{2}=0968$ and for bentonite are not actively providing the regression equation $\mathrm{y}=$ $1.435 \mathrm{x}+0.003$ and the value of $\mathrm{R}^{2}=0189$. Overall the regression equation obtained can be summarized in Table 2 .

From Table 3 it can be seen that the regression equation resulting from variations in the mass of bentonite and bentonite variation of contact time of the active and inactive. Langmuir isotherm adsorption isotherm is a model that uses the assumption that the surface of the adsorbent have switched on any number of sites can adsorb the active site of the molecule adsorbate and when any active sites that have been adsorbed adsorbate then the adsorbent is already unlikely to be able to adsorb again. Langmuir isotherm indicate that the adsorption process occurs chemically active sites that bentonite will interact with hydroxyl groups contained on $\mathrm{Cu}$ by forming hydrogen bonds.

\section{Conclusion}

The ability of bentonite that has been activated in absorbing Copper $(\mathrm{Cu})$ smaller than the bentonite which has not been activated. Bentonite is not activated efficiency has $97.7 \%$ while the activated bentonite has 
the absorption efficiency of $82.5 \%$ with a contact time of 30 minutes. Langmuir isotherm with the price of $r$ close to 1 indicates that the adsorption process occurs chemically active sites that bentonite will interact with hydroxyl groups contained on $\mathrm{Cu}$ by forming hydrogen bonds in a single layer (monolayer)

\section{Acknowledgment}

The author would like to thank the head and employees Basic chemistry laboratory and laboratory University of Jambi, Jambi University Research Center Head and the Ministry of Research and Technology of the Republic of Indonesian who has helped finance this research.

\section{Author's Constributions}

Susila Arita: Designed the research plan and organized the Research.

Muhammad Naswir: Design and, participated in all experiments, data collection, data-analysis and writing of the manuscript.

Irma Astriana: Data collection and participated in all experiments and Scriptwriting. discussion of the contents of the manuscript.

Nelson: Analisys data, Scriptwriting. discussion of the contents of the manuscript.

\section{References}

Al-Jlil, S.A., 2010. Heavy metal reduction of industry waste by using bentonite and roasty clay. Sci. Technol., 5: 138-145.

DOI: $10.3923 /$ tasr. 2010. 138.145

Apriliana, P. and I.K. Dewi, 2015. Adsorption of metals $\mathrm{Pb}^{2+}$ and $\mathrm{Cu}^{2+}$ by activated bentonite base $(\mathrm{NaOH})$. J. Chem., 9: 235-242.

Bath, D., 2012. Land use bentonite as adsorbent metal $\mathrm{Cu}$. Scientific J. Chem. Eng.

Christidis, G.E., P.W. Scott and A.C. Dunham, 1997. Acid activation and bleaching capacity of bentonites from the islands of Milos and Chios, Aegean, Greece. Applied Clay Sci., 12: 329-347. DOI: 10.1016/S0169-1317(97)00017-3

Faizal, M., 2014. Containing Waste Water Treatment Using heavy metal composite adsorbent with Bentonite and $\mathrm{Fe}_{3} \mathrm{O}_{4}$. J. Chem. Eng.

Fatimah, I., 2014. Adsorption and catalysis using claybased materials. Graha Science, Yogyakarta.

Hutagalung, H.P., 1991. Sea pollution by heavy metal. Oceanology Research Center, Sea Pollution Status in Indonesia and Monitoring Techniques, LIPI, Jakarta.
Istighfaro, N., 2010. Improved cooking oil with adsorption method using bentonite-activated carbon moringa seeds. UIN, Malang, Indoensian.

Komadel, P., 2003. Chemically modified smectites. Clay Miner., 38: 127-138. DOI: $10.1180 / 0009855033810083$

Miller, J.C. and J.N. Miller, 1991. Statistics for analytical chemistry. ITB, Bandung, Indonesian.

Naswir, M., S. Arita, M. Marsi and S. Salni, 2015. Treatment of peat water using local raw material formulations of Jambi, Indonesia. Asian J. Chem., 27: 3951-3955. DOI: 10.14233/ajchem.2015.18963

Naswir, M., S. Arita, Marsi and Salni, 2013. Characterization of bentonit by XRD and SEM-EDS and use to incease $\mathrm{pH}$ and color removal, $\mathrm{Fe}$ and organic subtance in peat water. J. Clean Energy Technol., 1: 313-317. DOI: $10.7763 /$ JOCET.2013.V1.71

Notohadiprawiro, T., 1993. Heavy metals in agriculture. Manuscript Lecture in Palm Research Center, Medan, Indonesian.

Prasetyowati, Yuni, Koestari and Toeti, 2014. Bentonite adsorption capacity technical as adsorbent ion $\mathrm{Cd}^{2+}$. UNESA J. Chem.

Ramadani and Eko, 2011. Effect of $\mathrm{H}_{2} \mathrm{SO}_{4}$ concentration and weight of natural activated bentonite and commercial. The absorption of heavy metals Cadmium $(\mathrm{Cd})$ and copper $(\mathrm{Cu})$ in solution $\mathrm{Cu}$ and $\mathrm{Cd}$ Standard with AAS method. Sumatera Utara University, Indonesian.

Sainz-Diaz, C.I., A. Hernandez-Laguna and M.T. Dove, 2001. Modeling of dioctahedral 2:1 phyllosilicates by means of transferable empirical potentials. Phys. Chem. Mineral., 28: 130-141. DOI: $10.1007 / \mathrm{s} 002690000139$

Salamah, S., 2008. Activated carbon manufacture of fruit leather mahogany treatment immersion in $\mathrm{KOH}$ solution. Proceedings of the National Seminar Teknoin, (NST' 08), Field of Chemical Engineering and Textile.

Sembiring, Z., Buhani, Suharso and Sumadi., 2009. The isothermic adsorption of $\mathrm{Pb}(\mathrm{II}), \mathrm{Cu}(\mathrm{II})$ and $\mathrm{Cd}(\mathrm{II})$ ions on Nannochloropsis sp encapsulated by silica aquagel. Indo. J. Chem., 9: 1-5. DOI: 10.22146/ijc.21556

Suarya, P., 2008. Clove leaf oil impurity adsorption by acid activated clay. State University of Udayana.

Weber, W.J., 1972. Physics chemical processfor water quality control. John, New York.

Yusnimar and Drastinawati, 2005. Utilization of bentonite as adsorbent on palm oil bleaching process. Proceedings of the National Seminar on Technology Petro-oleochemical, (TPO’ 05), Riau Indonesian. 